\title{
ANALISIS FAKTOR-FAKTOR YANG MEMPENGARUHI PRODUKSI GAMBIR
}

\author{
Nur Sindy Oktavia \\ Universitas Andalas \\ Nursindyoktavia18@gmail.com
}

\begin{abstract}
Abstrak: Meskipun sudah banyak studi tentang faktor-faktor yang mempengaruhi produksi, namun untuk faktor-faktor yang mempengaruhi jumlah produksi gambir masih jarang peneliti yang melakukan penelitian. Penelitian sebelumnya tentang faktor-faktor yang mempengaruhi produksi kakao, padi dan jeruk. Tujuan dari penelitian ini adalah menganalisis pengaruh penggunaan faktor produksi berupa luas lahan, tenaga kerja, harga gambir, penggunaan pupuk, umur tanaman, pengalaman petani dan penggunaan pestisida terhadap jumlah produksi gambir. Hasil penelitian menunjukkan bahwa variabel luas lahan, tenaga kerja, penggunaan pupuk dan penggunaan pestisida dapat meningkatkan jumlah produksi gambir secara positif dan signifikan. Variabel harga gambir, umur tanaman dan pengalaman petani berpengaruh postif dan tidak signifikan terhadap jumlah produksi gambir.
\end{abstract}

Kata Kunci: Gambir dan Faktor Produksi

Abstract: Although there have been many studies on the factors that affect the production, but for the factors that affect the amount of gambier production, it is still rare for researchers to conduct research. Previous research on the factors that affect the production of cocoa, rice and citrus. The purpose of this research is to analyze the effect of the usage of production factor in the form of land area, labor, gambier price, fertilizer, plant age, farmer experience and the usage of pesticides on the amount of gambier productionKeywords: Gambier and Production Factors. The results showed that variable land area, labor, fertilizer and pesticide usage could increase the amount of gambier production positively and significantly. The variables of gambier price, plant age and farmer's experience have a positive and insignificant effect on the amount of gambier production.

Keywords: Gambier and Production Factors

\section{A. PENDAhULUAN}

Salah satu komoditas subsektor perkebunan yang penting adalah komoditas gambir (Uncaria gambier Roxb). Tanaman gambir merupakan tanaman perdu, termasuk salah satu di antara famili Rubiace (kopi-kopian) yang memiliki nilai ekonomi tinggi, yaitu dari ekstrak (getah) daun dan ranting mengandung asam katechu tannat (tanin), katechin, pyrocatecol, florisin, lilin, fixed oil. Thorper dan Whiteley (dikutip dari Dhalimi, 2006) menyatakan bahwa kandungan utama gambir adalah asam katechu tannat (20-50 persen), katechin (7-33 persen), dan pyrocatechol (20-30 persen), sedangkan yang lainnya dalam jumlah terbatas. Bachtiar (dikutip dari Dahlimi, 2006) menyatakan bahwa kandungan kimia gambir yang paling banyak dimanfaatkan adalah katechin dan katechu tannat (tanin).

Simanjuntak (2001) menyatakan bahwa secara kuantitatif, produktivitas merupakan perbandingan antara hasil yang dicapai (keluaran) dengan keseluruhan sumber (masukan) yang dipergunakan persatuan waktu. Peningkatan produktivitas dapat terwujud dalam 4 macam bentuk, yaitu; (1) Jumlah produksi yang sama dapat diperoleh dengan menggunakan sumber daya yang lebih sedikit; (2) Jumlah produksi yang besar dapat dicapai dengan menggunakan sumber daya yang kurang; (3) Jumlah produksi yang lebih besar dapat dicapai dengan menggunakan sumber daya yang sama; (4) Jumlah produksi yang jauh lebih besar dapat dicapai dengan pertambahan sumber daya yang relatif kurang atau lebih sedikit. 
Penelitian yang dilakukan oleh Fauza (2011) menyatakan bahwa gambir merupakan komoditas spesifik Indonesia yang pada saat ini lebih banyak dihasilkan di Sumatera Barat, secara ekonomi mempunyai prospek untuk dikembangkan di masa yang akan datang. Selain mempunyai prospek dan peluang, dalam pengembangannya terdapat banyak permasalahan dan tantangan yang perlu dicarikan solusinya. Pengembangan usaha perkebunan dan industri gambir akan berhasil dengan menanggulangi berbagai tantangan dan kendala secara utuh dan komprehensif mulai dari perakitan varietas unggul, teknik budidaya, pengolahan hasil, sosial ekonomi, sosial budaya serta kelembagaan berdasarkan prinsip pertanian yang berkelanjutan dan berwawasan lingkungan, dan diversifikasi produk turunannya melalui peran serta berbagai pihak terkait, industriawan perbenihan (pemula), petani, pedagang, investor, peneliti, penyuluh, dan pemerintah.

\section{B. METODE PENELITIAN}

Tulisan ini membahas analisis faktor-faktor yang mempengaruhi produksi usahatani gambir.Usahatani adalah ilmu yang mempelajari tentang cara petani mengelola input atau faktorfaktor produksi (tanah, tenaga kerja, teknologi, pupuk, benih, dan pestisida) dengan efektif, efisien dan continue untuk menghasilkan produksi yang tinggi sehingga pendapatan usahataninya meningkat (Abd. Rahim dan Diah Retno Dwi Hastuti, 2007).

Pyndick dan Rubinfeld (1999) menyatakan bahwa produksi adalah suatu perubahan dua atau lebih input menjadi satu atau lebih output. Dalam berproduksi membutuhkan beberapa unit input. Dalam konteks pertanian, sejumlah unit input yang lazim digunakan antara lain adalah modal, tenaga kerja dan teknologi. Maka dari itu, ada sebuah hubungan antara input dan produksi yaitu output maksimal yang diperoleh dari sejumlah input tertentu atau biasa disebut fungsi produksi. Faktor produksi dalam istilah ekonomi seringkali disebut dengan input. Produksi dan faktor produksi memiliki hubungan yang kuat. Soekartawi (1990) menyatakan hubungan tersebut dapat dirumuskan sebagai berikut :

$$
\mathrm{Y}=\mathrm{f}(\mathrm{X} 1, \mathrm{X} 2, \ldots \ldots \ldots . \mathrm{Xi})
$$

Dimana $\mathrm{Y}$ merupakan variabel (produksi) yang dipengaruhi variabel $\mathrm{X}$ (faktor produksi) manakala X merupakan variabel (faktor produksi) yang mempengaruhi variabel $\mathrm{Y}$ (produksi).

Dalam proses produksi, perusahaan akan mengubah input menjadi output atau produk. Input yang juga disebut sebagai faktor-faktor produksi adalah faktor-faktor yang digunakan dalam proses produksi. Selanjutnya, input dapat digolongkan ke dalam beberapa kategori seperti tenaga kerja, bahan baku dan modal, dimana masing-masing tersebut dapat digolongkan lebih rinci lagi. Dalam sebuah usaha, pengusaha tentunya dapat mengubah input yang dimiliki menjadi output yang diinginkan dengan berbagai cara melalui variasi penggunaan tenaga kerja, bahan-bahan produksi dan modal. Hubungan antara input produksi, proses dan produk yang dihasilkan dapat dijelaskan dalam sebuah fungsi produksi (Pindyck, 2009).

Secara umum, fungsi produksi dapat dirumuskan sebagai berikut :

Dimana:

$$
\mathrm{Q}=\mathrm{f}\left(\mathrm{X}_{1}, \mathrm{X}_{2}, \mathrm{X}_{3} \ldots \ldots . ., \mathrm{X}_{\mathrm{i}}\right)
$$

$\mathrm{Q}=$ Output

$\mathrm{X}_{\mathrm{i}}=$ Input yang digunakan dalam proses produksi, $\mathrm{i}=1,2,3 \ldots \ldots \ldots, \mathrm{n}$.

Input yang digunakan contohnya adalah modal, tenaga kerja, dummy, dan lain-lain. Oleh karena itu, seringkali persamaan fungsi produksi juga dirumuskan sebagai berikut :

Dimana :

$$
\mathrm{Q}=\mathrm{f}(\mathrm{K}, \mathrm{L})
$$

$\mathrm{Q}=$ Output

$\mathrm{K}=$ Kapital/Modal

$\mathrm{L}=$ Tenaga Kerja

Persamaan tersebut menghubungkan jumlah output dari jumlah kedua input, yaitu modal dan tenaga kerja. Fungsi produksi memungkinkan semua input dikombinasi dengan berbagai perbandingan untuk menghasilkan jumlah output dengan berbagai cara. Fungsi produksi juga menunjukkan output terbesar yang dihasilkan suatu perusahaan untuk kombinasi input tertentu. 
Fungsi produksi menggambarkan apa yang secara teknis layak, dan usaha beroperasi secara efisien, yaitu apabila perusahaan menggunakan setiap kombinasi input seefektif mungkin.

\section{HASIL DAN PEMBAHASAN}

\section{Produksi Jangka Panjang dan Produksi Jangka Pendek}

Sebuah usaha atau bisnis membutuhkan waktu untuk mengubah jumlah komponen tenaga kerja dan modal dalam memproduksi hasil akhir. Sebelum mulai beroperasi sebuah usaha harus direncanakan dan dibangun terlebih dahulu. Sebuah perusahaan juga harus mempertimbangkan kemampuannya dalam memvariasikan input serta lama waktu yang dibutuhkan. Dalam menganalisis produksi juga penting untuk membedakan periode waktu antara jangka panjang atau jangka pendek.

Jangka pendek mengacu pada periode waktu dimana satu atau lebih faktor produksi tidak dapat diubah atau tidak dapat divariasikan, seperti sebuah faktor yang disebut input tetap (fixed input). Sedangkan jangka panjang adalah jumlah waktu yang dibutuhkan untuk mengubah semua input menjadi variabel input. Pada kenyataannya tidak ada periode waktu yang spesifik untuk menyatakan sebuah periode termasuk jangka pendek atau jangka panjang. Perusahaan akan mengubah jumlah komponen inputnya sebagai upaya untuk meminimalkan biaya produksi.

\section{a. Produksi dengan Satu Input Variabel (Tenaga Kerja)}

Dalam produksi dengan menggunakan satu input variabel, modal dianggap tetap dan tenaga kerja diasumsikan berubah, satu-satunya cara yang dapat dilakukan perusahaan untuk meningkatkan output adalah dengan menambah jumlah tenaga kerja. Pada awalnya setiap unit tambahan tenaga kerja dapat mengambil manfaat yang semakin besar dari mesin dan pabrik yang ada, setelah sampai pada titik tertentu tenaga kerja tambahan tidak lagi berguna dan menjadi tidak produktif lagi.

Setiap kontribusi yang diberikan oleh tenaga kerja pada proses produksi dapat digambarkan dengan pengertian produk rata-rata dan produk marjinal. Produk rata-rata merupakan output per unit dari input tertentu, sedangkan produk marjinal merupakan tambahan output yang diproduksi ketika terjadi penambahan input sebesar 1 unit. Dalam fungsi produksi dengan menggunakan satu input variabel berlaku The Law of Diminishing Marginal Return atau hukum hasil yang semakin menurun. Hukum tersebut menyatakan bahwa jika penggunaan satu input meningkat sementara input yang lain tetap, sampai pada titik tertentu penambahan input tersebut akan mengurangi output.

\section{Gambar 2.1}

Produksi dengan Satu Variabel Input

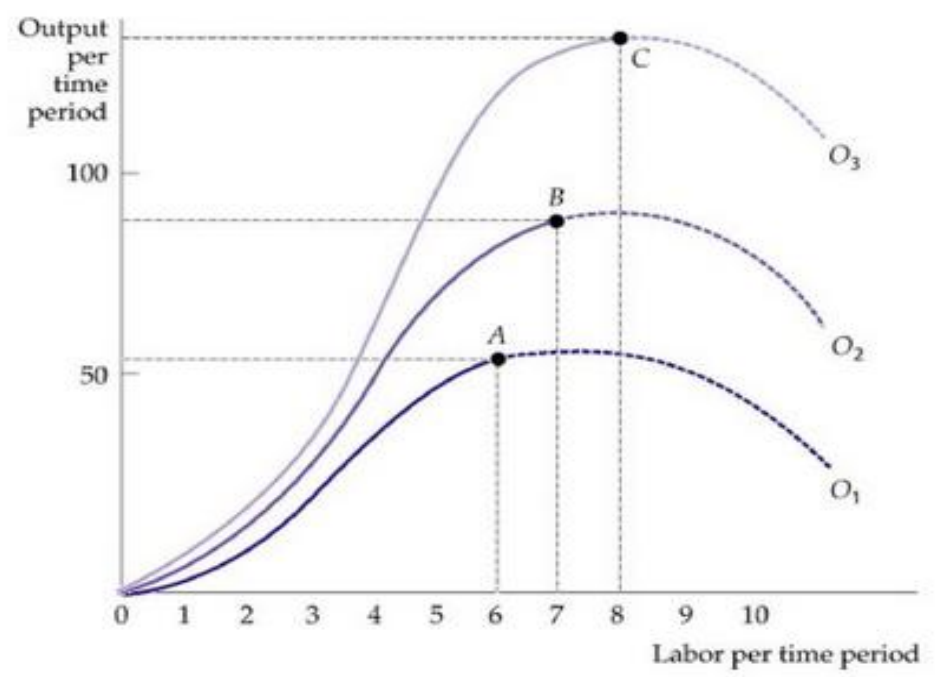

Sumber : Pindyck, (2009)

Perbaikan teknologi akan menyebabkan produktivitas tenaga kerja menjadi meningkat, meskipun setiap proses produksi tertentu akan menurunkan output dari tenaga kerja. Pergerakan dari titik A menuju titik B dan titik $\mathrm{C}$ menunjukkan bahwa produktivitas tenaga kerja semakin meningkat. 


\section{b. Produksi dengan Dua Input Variabel}

Fungsi produksi jangka panjang merupakan kondisi dimana kedua input yaitu tenaga kerja dan modal bersifat tidak tetap atau berubah-ubah. Perusahaan dapat memproduksi outputnya dengan cara mengkombinasikan berbagai jumlah tenaga kerja dan modal. Berbagai kombinasi input dapat dijelaskan melalui kurva isokuan, yaitu kurva yang menggambarkan semua kemungkinan kombinasi dari input yang menghasilkan output yang sama. Beberapa gabungan kurva isokuan akan membentuk peta isokuan dan merupakan cara lain untuk menggambarkan fungsi produksi.

Gambar 2.2

Produksi dengan Dua Variabel Input

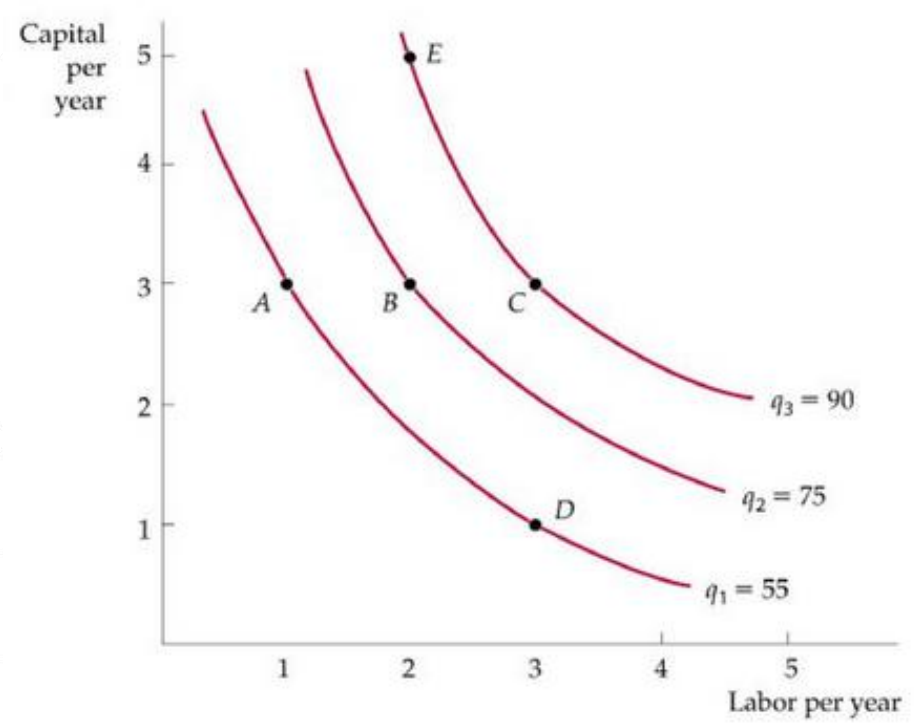

Sumber : Pindyck, (2009)

Isokuan produksi menunjukkan berbagai kombinasi input yang diperlukan sebuah perusahaan untuk memproduksi sejumlah output tertentu. Peta isokuan menunjukkan fungsi produksi perusahaan. Output bertambah ketika isokuan bergeser dari Q1 menuju Q2 dan selanjutnya ke Q3.

Isokuan produksi menunjukkan berbagai kombinasi input yang diperlukan sebuah perusahaan untuk memproduksi sejumlah output tertentu. Peta Isokuan menunjukkan fungsi produksi perusahaan. Output bertambah ketika isokuan bergerak dari Q1 menuju Q2 dan selanjutnya menuju Q3. Isokuan menunjukkan suatu fleksibelitas yang dimiliki perusahaan ketika membuat keputusan produksi bahwa perusahaan pada umumnya menetapkan suatu jumlah output dengan menggantikan satu input dengan lainnya.

Dalam fungsi produksi berlaku hukum tambahan penerimaan yang semakin menurun atau dikenal diminishing marginal return, hal ini terjadi ketika setiap tambahan unit tenaga kerja menyebabkan semakin sedikit output tambahan. Menambah satu faktor sedangkan faktor lainnya tetap konstan menyebabkan kenaikan yang semakin rendah pada output, isokuan menjadi lebih curam apabila lebih banyak modal yang ditambah daripada tenaga kerja, dan isokuannya lebih datar apabila tenaga kerja lebih banyak ditambah daripada modal.

Kemiringan dari setiap isokuan menunjukkan bagaimana jumlah dari satu input dapat ditukarkan terhadap jumlah input yang lain. Tingkat substitusi teknis marjinal adalah suatu jumlah dimana terjadi pengurangan satu input namun menambah satu input lain, sehingga output tetap konstan. Tingkat substitusi teknis marjinal semakin berkurang ketika semakin banyak tenaga kerja ditambahkan pada proses produksi sebagai substitusi modal, produktivitas tenaga kerja menurun. Sebaliknya, apabila lebih banyak modal yang ditambahkan daripada tenaga kerja produktivitas modal akan menurun.

Soekartawi (1990) mengemukakan bahwa fungsi produksi dianggap penting, sebab :

a) Fungsi produksi dapat menjelaskan hubungan antara faktor produksi dengan produksi itu sendiri secara langsung yang mudah dipahami. 
b) Fungsi produksi dapat menjelaskan hubungan antara variabel yang dijelaskan atau dependent variable $(\mathrm{Y})$, dengan variabel yang menjelaskan atau independent variable $(\mathrm{X})$ dan juga mampu mengetahui hubungan antar variabel penjelasnya (antara $\mathrm{X}$ dengan $\mathrm{X}$ yang lainnya).

Penelitian yang dilakukan oleh Ginting, dkk (2017) menyatakan bahwa luas lahan dan modal usaha berpengaruh signifikan terhadap produksi komoditi kopi, karena luas lahan dan modal yang besar akan meningkatkan produksi komoditi kopi di Kabupaten Humbang Hasundutan. Harga kopi berpengaruh namun tidak signifikan terhadap produksi kopi, karena sebagian besar petani di daerah penelitian tidak menjual hasil produksinya secara langsung ke pasar melainkan menjual kepada pedagang pengumpul (agen), sehingga harga yang diterima petani sangat rendah. Pendidikan petani, pengalaman bertani, harga pupuk, harga obat-obatan dan penyuluhan tidak berpengaruh signifikan terhadap produksi komoditi kopi di Kabupaten Humbang Hasundutan.

Penelitian yang dilakukan oleh Arifin, dkk (2014) di Indonesia menyatakan bahwa faktor-faktor yang mempengaruhi produksi padi adalah luas lahan, upah tenaga kerja, harga benih, harga pupuk urea, harga pupuk sp, harga pestisida, pengalaman petani dan kepemilikan lahan. Luas lahan berpengaruh signifikan terhadap peningkatan produksi. Penambahan lahan pertanian memungkinkan petani untuk meningkatkan keuntungan pertanian padi di sawah tadah hujan. Semakin besar luas lahan yang diperoleh dari pertanian padi, semakin besar keuntungannya diperoleh oleh petani.

Ini sesuai dengan hasil penelitian Damanik (2014), menyatakan luas lahan sudah positif dan signifikan terhadap pendapatan petani padi. Ini juga sesuai dengan teori jika petani mampu mengelola pertanian secara maksimal dengan penambahan lahan yang dikelola, peluang untuk mendapatkan lebih banyak produksi dan keuntungan juga bisa meningkat. Variabel pengalaman petani juga menunjukkan efek yang signifikan terhadap produksi pertanian. Ini menunjukkan bahwa pada umumnya di daerah penelitian sebagian besar penduduknya adalah petani. Para petani telah lama bertani dan bercocok tanam sebagai mata pencahariannya. Pertanian padi adalah bagian dari hidupnya, untuk melangsungkan kehidupannya dia harus bertani. Petani yang sudah lama bertani dapat meningkatkan pengalaman bagi petani untuk menyelesaikan setiap masalah yang dihadapi di pertanian. Pengalaman yang lama secara tidak langsung memiliki efek positif untuk meningkatkan produksi dan keuntungan yang diperoleh petani dari usahatani padi yang dilakukan. Dapat disimpulkan bahwa produksi dan profitalitas padi disawah tadah hujan berdasarkan kepemilikan lahan sangat menguntungkan petani padi. Faktor-faktor tersebut signifikan terhadap usahatani padi di Indonesia.

Pemerintah diharapkan memperhatikan kesejahteraan petani khususnya pemerintah yang bekerja di lahan orang lain dengan menerapkan sistem bagi hasil. Pemerintah diharapkan untuk menerapkan kebijakan untuk mensejahterakan petani. Penggunaan faktor produksi atau input produksi harus dipertimbangkandalam kegiatan pertanian untuk menghindari penggunaan berlebihan yang dapat merugikan petani atau mempengaruhi pendapatan dan mengarah pada produksi yang tidak optimal.

Penelitian yang dilakukan oleh Adeniyi dan Ogunsola (2014) di Nigeria menyatakan bahwa faktor-faktor yang mempengaruhi hasil produksi kakao adalah jumlah pupuk yang digunakan, jumlah tenaga kerja upahan, jumlah tenaga kerja keluarga, usia tanaman kakao, luas lahan kakao, jam ekstra dihabiskan untuk semprot ulang setelah curah hujan tidak terduga. Jumlah pupuk yang digunakan, jumlah tenaga kerja upahan, jumlah tenaga kerja keluarga, luas lahan kakao, jam ekstra dihabiskan untuk semprot ulang setelah curah hujan tidak terduga berpengaruh positif dan signifikan terhadap hasil produksi kakao, sedangkan umur tanaman kakao berpengaruh negatif dan signifikan terhadap hasil produksi kakao, karna setelah usia 30-45 tahun produktivitasnya menurun dan akhirnya hampir tidak produktif.

Penelitian yang dilakukan oleh Namah dan Dina (2010) mengkaji faktor-faktor yang mempengaruhi produksi Jeruk Keprok Soe dan mengkaji faktor-faktor yang mempengaruhi pendapatan usahatani Jeruk Keprok Soe. Alat analisis yang dipakai menggunakan fungsi produksi Cobb-Douglas. Dalam jurnal penelitian ini, pada persamaan pertama yaitu faktor-faktor yang mempengaruhi tingkat produksi, variabel dependen yang digunakan adalah produksi jeruk keprok soe (ton), dan variabel independen adalah umur tanaman (tahun), luas lahan (ha), pupuk (kg), tenaga kerja (HOK), pengalaman petani (tahun), dummy 1= pendidikan SLTP/SLTA, dummy 2 = pendidikan Diploma/Sarjana. Kemudian faktor-faktor yang mempengaruhi tingkat pendapatan, variabel dependennya adalah pendapatan yang telah di normalkan (Rp), dan variabel independennya adalah 
umur petani (tahun), luas lahan (ha), harga jeruk keprok yang dinormalkan (Rp), upah tenaga kerja dinormalkan (Rp), pengalaman (tahun) dan harga bibit dinormalkan (Rp).

Dari estimasi hasil analisis regresi menunjukkan bahwa umur tanaman berpengaruh negatif terhadap produksi Jeruk Keprok Soe, luas lahan berpengaruh positif terhadap produksi Jeruk Keprok Soe, pupuk berpengaruh positif terhadap produksi Jeruk Keprok Soe, curahan tenaga kerja berpengaruh positif terhadap produksi Jeruk Keprok Soe, pengalaman berpengaruh positif terhadap produksi Jeruk Keprok Soe. Umur petani, pengalaman, luas lahan berpengaruh positif terhadap pendapatan usahatani Jeruk Keprok Soe dan variabel harga bibit, upah tenaga kerja, pendidikan berpengaruh negatif terhadap pendapatan usahatani Jeruk Keprok Soe.

Penelitan Aboki, dkk (2013) di Nigeria menyatakan bahwa luas lahan, tenaga kerja keluarga, tenaga kerja luar keluarga, dan pupuk berpengaruh nyata baik pada tingkat kepercayaan 1 persen maupun 5 persen. Hasil menunjukkan nilai efisiensi teknis, ekonomis, dan alokatif masing-masing sebesar $0,887,0,825$, dan 0,859 yang bermakna bahwa petani sampel relatif sangat efisien dalam mengalokasian sumber daya terbatasnya dengan efisiensi teknis nampak lebih signifikan dibanding dengan efisiensi alokatif dan efisiensi ekonomis. Dan diperoleh dari 300 petani yang disampel melalui metode purposive sampling. Data dianalisis menggunakan statistik deskriptif, fungsi produksi frontier stokastik, dan fungsi biaya. Hasil penelitian juga menunjukkan bahwa faktor utama yang mempengaruhi produksi ubi adalah luas lahan, tenaga kerja keluarga, tenaga kerja luar keluarga, pupuk, ukuran rumah tangga, lama sekolah, dan sumber pendanaan. Faktor-faktor tersebut signifikan dan mempunyai pengaruh positif terhadap produksi ubi. Dalam rangka meningkatkan produksi, petani juga diharapkan lebih menekankan pada faktor-faktor yang berkaitan dengan kebiasaan (culture) dibanding menambah luas lahan.

Aligori (2013) penelitiannya yang berjudul "Efisiensi Produksi Usaha Garam Rakyat di Kabupaten Indramayu" dimana penelitian tersebut menguji efisiensi ekonomi produksi usaha garam rakyat selama 2011 dengan gambaran untuk memeriksa efisiensi produktif garam yang dikelola oleh karakteristik petambak garam di tiga wilayah sentra produksi garam Kabupaten Indramayu. Data dikumpulkan dari 100 petani yang dikelompokkan menjadi tiga kelompok dari perbedaan kepemilikan tenure yang dipilih dengan menggunakan teknik multistage sampling dan dianalisis menggunakan statistik deskriptif inperensia dengan memakai fungsi Cobb-Douglas stochastic-frontier dengan teknologi yang tersedia. Pendugaan model fungsi produksi stochastic-frontier dilakukan dua tahap yaitu menggunakan : 1) Metode ordinary least square (OLS) yang digunakan sebagai fungsi deterministik batas frontier. 2) Metode maximum likelihood estimation (MLE) yang digunakan untuk melihat perbandingan tingkat produksi yang disebabkan oleh efek in-efisiensi teknis dan noise.Pendugaan OLS menghasilkan RTS yang dimana produksi garam pada daerah increasing return to scale dimana nilai RTS petambak sewa 2.670 , petambak bagi hasil 1.350 , dan petambak pemilikgarap 1.153. Hasil analisis lain menunjukkan bahwa kehadiran in-efisiensi teknis dan efisiensi alokatif memiliki efek dalam produksi garam seperti yang digambarkan oleh estimasi koefisien gamma yang singnifikan pada masing-masing petambak. Parameter estimasi gamma untuk fungsi produksi petambak sewa 0,801 , petambak bgai-hasil 0,990 dan petambak pemilik-garap 0,990 yang menunjukkan bahwa sekitar 80,1 persen, 99 persen dari variasi dalam output dari usaha garam antara petambak garam adalah karena perbedaan dalam efisiensi teknis mereka.

Hasil penelitian menunjukkan bahwa meningkatnya ukuran lahan, pendapatan, dan adanya akses kredit pinjaman modal di tingkat petambak sewa secara nyata menyebabkan penambahan efisiensi. Pemakaian zat aditif dapat meningkatan efisiensi pada petambak pemilik-garap. Tingkat rata-rata efisiensi teknis 68 persen di atas 0,7 sisanya dibawah skala tersebut. Tingkat efisiensi alokatif tercapai hanya 5 persen dari total sampel petambak yang di dominasi oleh petambak pemilik-garap. Dengan uji optimalisasi alokasi input produksi melalui rasio nilai marjinal produk terhadap biaya korbanan (pada harga output Rp. 450 per kg) terlihat faktor lahan dan tenaga kerja lebih besar dari satu artinya perlu adanya peningkatan terhadap luas lahan dan peningkatan kualitas tenaga kerja. Jika lahan di tingkatkan peluang untuk mendapatkan pendapatan petambak sewa mencapai 3 persen, 12 persen petambak bagi-hasil dan 15 persen petambak pemilik-garap. Masih rendahnya tingkat pendapatan petambak pemilik-garap sekarang disebabkan belum tercapai skala ekonomis yang disebabkan oleh kecilnya ukuran lahan (farm size) yang rata-rata menggarap 0,5 hektar tambak garam. 


\section{KESIMPULAN}

Berdasarkan hasil dan pembahasan yang telah dilakukan dalam penelitian sebelumnya, maka dapat diambil kesimpulan sebagai berikut :

1. Variabel luas lahan, tenaga kerja, penggunaan pupuk dan penggunaan pestisida memiliki pengaruh positif dan signifikan terhadap jumlah produksi gambir.

2. Variabel harga gambir, umur tanaman dan pengalaman petani berpengaruh postif dan tidak signifikan terhadap jumlah produksi gambir.

\section{E. DAFTAR PUSTAKA}

Arifin,Sofyan, Nirawati, Muhammad Arsyad Biba. 2014. "Profitability And Profit Factors Of Rice Farming In Rainfed Lowland Based On Land Tenure".International Journal Of Scientific \& Technology Research, Volume 7.

Aboki, E., A.A.U.Jongur, J.1. Onuand I.I. Umaru. 2013. Analysis of Technical, Economic and Allocative Efficiencies of Cassava Production in Taraba State, Nigeria. IOSR Journal of Agriculture and Veterinary Science. Volume 5.

Aligori, Ahsin. 2013. "Efficiency of Community-based Sald Production in Indramayu District".Thesis, Intitut Pertanian Bogor.

Abd. Rahim dan Diah Retno Dwi Hastuti. 2008. Pengantar Teori dan Kasus Ekonomika Pertanian. Jakarta: Penebar Swadaya.

Afrizal, Roni, 2009. "Analisis Produksi Dan Pemasaran Gambir di Kabupaten Lima Puluh Kota Provinsi Sumatera Barat". Thesis, Institut Pertanian Bogor.

Damanik, JA., 2014. "Analysis of Factors Affecting Rice-Farmers' Income in Sub-Regency Masaran, Regency of Sragen". Journal of Analysis of Economics Development, Vol. 3 (1) : 212 -224.

Dhalimi, Azmi. 2006."Permasalahan Gambir (Uncaria gambir L.) di Sumatera Barat dan Alternatif Pemecahannya". Indonesian Agriculture Technology Assessment and Developmen Institute, volume 5 nomor 1, juni 2006. Diambil dari :

http://ejurnal.litbang.pertanian.go.id/index.php/psp/article/viewFile/2916/2543 (21 Mei 2019).

Fauza, Hamda. 2011. "Perkembangan Usaha Perkebunan dan Industri Gambir di Sumatera Barat : Peluang dan Tantangan". Fakultas Pertanian Universitas Andalas.

Ginting, Albina Br.,Hotden L. Nainggolan, Gerald P. Siahaan.2017. "Analisis Faktor-Faktor Yang Mempengaruhi Sentra Produksi Komoditi Kopi Di Kabupaten Humbang Hasundutan".Jurnal Agrisep.

Mubyarto. 1995. Pengantar Ekonomi Pertanian Edisi Ketiga. Jakarta: LP3ES.

Moehar. 2001. Pengantar Ekonomi Pertanian. Jakarta : Bumi Aksara.

Namah, Chris Natali dan Dina Viktoria Sinlae. 2010. "Faktor-Faktor yang Mempengaruhi Produksi Dan Pendapatan Usahatani Jeruk Keprok Soe di Kabupaten Timor Tengah Selatan".Politeknik Pertanian Negeri Kupang. Vol. 99 No.1. Diambil dari : http://jurnal.politanikoe.ac.id/index.php/jp/article/view/120/117. (6 April 2019).

Pyndick, R.S., dan, D.L. Rubinfeld. 1999. Mikro Ekonomi. Terjemahan PT Indeks. Jakarta : Prehallindo. Salvatore, Dominick. 2005. Ekonomi Manajerial dalam Perekonomian Global. Jakarta :Salemba Empat.

Simanjuntak, Payaman. (2001). Pengantar Ekonomi Sumber Daya Manusia. Jakarta: LPFEUI.

Soekartawi. 1990. Teori Ekonomi Produksi. Jakarta: Rajawali Pers.

Sukirno, Sadono. 2000. Mikro Ekonomi Modern: Perkembangan Pemikiran dari klasik sampai Keynesian Baru, Edisi 1. Jakarta : PT Raja Grafindo.

Simanjuntak, Payaman. 2001. Pengantar Ekonomi Sumber Daya Manusia. Jakarta: LPFEUI. 